DOI.

https://doi.org/10.22219/fths.v2i1

Home Page Journal: ejournal.umm.ac.id/index.php/fths/abou

Received: November 2018

Accepted: Desember 2018

Available online: Februari 2019

\title{
PENGARUH FORMULA SOSIS DENGAN PENAMBAHAN TEPUNG BIT (Beta vulgaris) PADA MUTU SOSIS DAGING BURUNG PUYUH AFKIR (Coturnix coturnix Japonica)
}

\author{
Nelis Oetavi A. ${ }^{1}$, Elfi Anis Sa'ati. ${ }^{*}$, Khusnul Khotimah ${ }^{2}$ \\ ${ }^{1}$ Program Studi Ilmu dan Teknologi Pangan, Fakultas Pertanian Peternakan Universitas \\ Muhammadiyah Malang, Malang, Indonesia \\ ${ }^{2}$ Program Studi Peternakan, Fakultas Pertanian Peternakan Universitas Muhammadiyah \\ Malang, Malang, Indonesia \\ *Corresponding author email : elfi@umm.ac.id
}

\begin{abstract}
Sausage is a popular food product consumed by the world's population. Meat quail (Coturnix coturnix) is a meat product which has good prospects for use as a raw material for making sausages. The superiority of quail meat is a high protein content between $16.78 \%-20.40 \%$ and about $70-74 \%$ yield of the weight of quail life. In order to increase consumer's acceptability, the sausage need a quality improvement especially in terms of appearance (color). One of the ingredients which has the potential as a natural dye is a beetroot (Beta vulgaris). The beetroot has a content of $200 \mathrm{mg}$ of betanin/100 g. This study aims to determine the effect of different sausage formulas and concentration of beetroot flour toward physicochemical and sensory properties of quail meat sausage. The research method used Randomized Block Design (RBD) with variation of beetroot flour concentration $(0 \%, 1 \%, 2 \%, 3 \%, 4 \%$, and $5 \% \mathrm{w} / \mathrm{w}$ of quail meat). Parameters analyzed were moisture content, protein content, fat content, ash content, antioxidant activity, texture, brightness, redness, yellowish, aroma, taste and appearance. The best treatment is the quail meat sausage with the addition of the concentration of beet flour by $5 \%$ with water content $63.52 \%$, protein content $13.44 \%$, fat content $3.80 \%$, ash $2.81 \%$, antioxidant activity $47.95 \%$, texture $5.19 \mathrm{~N} / \mathrm{mm} 2$, lightness 44.33 , redness 25.47 , yellowish 13.20 , aroma 3.4 of 5.00, taste 3.5 of 5.00, and appearance 4.04 of 5.00. All treatments have been in accordance with the standards based on SNI No. 01-3820-1995.
\end{abstract}

Keywords: beetroot flour, quail meat, sausage

\section{PENDAHULUAN}

Pembangunan bidang pangan gizi dan kesehatan di Indonesia adalah isu penting yang harus diperhatikan dan diperbaiki. Produk daging mempunyai peranan yang cukup penting dalam pemenuhan kebutuhan gizi dan pendukung kesehatan masyarakat. Namun, secara nasional pencapaian konsumsi protein hewani masih jauh dari standar. Berdasarkan data Pusat Penganekaragaman Konsumsi dan Keamanan Pangan pada tahun 2010-2014 menunjukkan \%AKG konsumsi pangan hewani penduduk Indonesia masih dibawah 10\%. Daging puyuh (Coturnix coturnix) merupakan produk daging yang sedang dikembangkan dan memiliki prospek yang baik untuk memenuhi kebutuhan 
pangan masyarakat. Daging puyuh diperoleh dari burung puyuh afkir (burung puyuh betina yang sudah rendah produktivitasnya). Burung puyuh betina afkir diperoleh setelah \pm 18 bulan aktif produksi. Berdasarkan data Statistik Peternakan dan Kesehatan Hewan (2015), produksi nasional daging puyuh afkir mencapai 993 ton dan Jawa Timur masuk dalam 3 besar produsen setelah daerah Sumatera Barat dan D.I. Yogyakarta dengan produksi mencapai 124 ton. Selain itu daging puyuh memiliki keunggulan kandungan protein yang tinggi antara 16,78\%-20,40\% (Kartikayudha et al., 2014). Dalam usaha meningkatkan tingkat konsumsi protein hewani dapat dilakukan diversifikasi pengolahan daging burung puyuh afkir menjadi hasil olahan yang banyak digemari masyarakat dan bernilai gizi tinggi. Diantaranya adalah dengan mengolahnya menjadi sosis. Sosis adalah salah satu produk makanan yang sangat populer dikonsumsi oleh penduduk dunia. Agar daya terima sosis daging puyuh terhadap konsumen meningkat diperlukan perbaikan kualitas terutama dari segi penampilannya. Warna adalah salah satu indeks penerimaan masyarakat terhadap makanan. Menurut Widodo, (2008) warna sosis akan cenderung kecoklatan karena dipengaruhi oleh komponen penyusunnya, baik dari jenis daging hingga bahan pengisi yang digunakan. Oleh karenanya diperlukan penambahan pewarna untuk memperindah tampilannya. Salah satu bahan yang memiliki potensi sebagai pewarna alami yaitu buah bit (Beta vulgaris) yang ditepungkan. Menurut Nottingham (2004), umbi bit mengandung pigmen betalain yang kompleks. Pigmen warna merah-ungu pada umbi bit merupakan turunan dari betasianin yang disebut betanin. Umbi bit memiliki kandungan betanin mencapai $200 \mathrm{mg} / 100 \mathrm{~g}$. Penggunaan tepung bit sebagai pewarna juga dapat berfungsi untuk mensubsitusi penggunaan nitrit pada produk daging. Adapun tujuan dari penelitian ini untuk mengetahui pengaruh perbedaan formula sosis dan konsentrasi tepung bit terhadap sifat fisikokimia dan sensori sosis daging puyuh afkir yang dihasilkan.

\section{METODE PENELITIAN}

\section{Bahan}

Bahan yang digunakan dalam penelitian ini antara lain meliputi daging puyuh betina usia \pm 18 bulan produksi dengan bobot $\pm 90 \mathrm{~g}$ dan tepung bit yang dihasilkan dari umbi bit dengan umur panen \pm 3 bulan dan berat umbi segar \pm $200 \mathrm{~g}$.

Alat

Peralatan yang digunakan pada penelitian ini antara lain meliputi freezer, timbangan analitik ohaus pioneer, colour reader CR-10, spektrofotometer genesys 20 thermo spectronik, centrifuge Table Top PLC-03, oven WTC binder 7200 type:E53 dan digital thermostat waterbath $\mathrm{HH}-4$. 


\section{Pembuatan Tepung Bit}

Pembuatan tepung bit mengacu pada Wibawanto et al. (2014) dengan modifikasi. Tepung bit diperoleh dari umbi bit segar yang mengalami proses pengeringan dan penghalusan. Langkah pertama adalah pencucian umbi bit, kemudian bit dipotong menggunakan slicer sampai terbentuk lembaran. Bit merah kemudian direndam dalam larutan asam sitrat 0,5\% selama 10 menit. Bit ditiriskan kemudian dikeringkan menggunakan pengering kabinet pada suhu $50{ }^{\circ} \mathrm{C}$. Proses pengeringan dihentikan apabila telah mencapai kadar air 5,59\%. Buah bit yang telah dikeringkan kemudian diblender dan diayak dengan ukuran 60 mesh sehingga didapatkan serbuk bit yang homogen. Tepung bit yang dihasilkan dianalisis intensitas warnanya, aktivitas antioksidan dan rendemennya. Diagram alir pembuatan tepung bit dapat dilihat pada Gambar 5 .

\section{Pembuatan Sosis Daging Puyuh}

Pembuatan sosis merujuk pada Pasaribu (2009) dengan modifikasi. Daging burung puyuh di-thawing, ditambahkan garam dan es $20 \%$ untuk menghambat pertumbuhan mikroba dan kemudian digiling. Setelah itu ditambahkan minyak, $10 \%$ es dan susu skim $15 \%$, diaduk hingga homogen lalu ditambahkan bumbu yang meliputi bawang putih $2 \%$; lada $0,5 \%$; pala $0,2 \%$; dan gula $2 \%$. Kemudian ditambahkan tepung bit pada masing - masing perlakuan; B0 $0 \%$, B1 1\%, B2 2\%, B3 3\%, B4 4\% dan B5 5\%, 10\% es, karagenan 3\% dan tepung tapioka lalu dimasukkan, diaduk hingga homogen. Adonan kemudian dimasukkan kedalam selongsong sosis dan direbus selama $80-83^{\circ} \mathrm{C}$ selama 20 menit. Tabel 8 menunjukkan formulasi masing-masing perlakuan.

\section{Parameter Penelitian}

Pengamatan yang dilakukan pada produk sosis diantaranya kadar air, protein, abu, lemak, aktivitas antioksidan, tekstur, intensitas warna, organoleptik (aroma, rasa, dan kenampakan).

\section{Rancangan Percobaan dan Analisa Data}

Penelitian ini menggunakan Rancangan Acak Kelompok (RAK) sederhana yaitu dengan level penambahan tepung bit $0 \% \mathrm{~b} / \mathrm{b}$ daging puyuh (B0), $1 \% \mathrm{~b} / \mathrm{b}$ daging puyuh (B1), $2 \% \mathrm{~b} / \mathrm{b}$ daging puyuh (B2), $3 \% \mathrm{~b} / \mathrm{b}$ daging puyuh (B3), $4 \% \mathrm{~b} / \mathrm{b}$ daging puyuh (B4), dan $5 \% \mathrm{~b} / \mathrm{b}$ daging puyuh (B5). Setiap perlakuan diulang sebanyak 3 kali sehingga diperoleh 24 satuan percobaan. Data dianalisa dengan Analisa Ragam kemudian dilanjutkan dengan uji DMRT taraf $\alpha=5 \%$.

\section{HASIL DAN PEMBAHASAN}

\section{Kadar Air}

Berdasarkan hasil analisis sidik ragam menunjukkan perlakuan konsentrasi tepung bit berpengaruh nyata $(p<0,05)$ terhadap kadar air sosis. Rerata kadar air sosis pada beberapa level tepung bit disajikan pada Tabel 1. 
Tabel 1. Rerata Kadar Air, Protein, dan Abu (\%) Sosis Pada Berbagai Level Tepung Bit

\begin{tabular}{llccccc}
\hline & \multicolumn{3}{c}{ Kadar Air (\%) } & \multicolumn{2}{c}{ Kadar Protein } \\
Perlakuan & \multicolumn{3}{c}{ \%) } & \multicolumn{2}{c}{ Kadar Abu (\%) } \\
\hline B0 (0 g tepung bit) & 66,04 & $\mathrm{c}$ & 12,24 & $\mathrm{a}$ & 2,08 & $\mathrm{a}$ \\
B1 (1 g tepung bit) & 65,55 & $\mathrm{bc}$ & 12,40 & $\mathrm{a}$ & 2,37 & $\mathrm{ab}$ \\
B2 (2 g tepung bit) & 63,01 & $\mathrm{a}$ & 13,12 & $\mathrm{ab}$ & 2,57 & $\mathrm{bc}$ \\
B3 (3 g tepung bit) & 62,88 & $\mathrm{a}$ & 14,24 & $\mathrm{bc}$ & 2,61 & $\mathrm{bc}$ \\
B4 (4 g tepung bit) & 62,67 & $\mathrm{a}$ & 14,66 & $\mathrm{c}$ & 2,72 & $\mathrm{bc}$ \\
B5 (5 g tepung bit) & 63,52 & $\mathrm{ab}$ & 13,44 & $\mathrm{ab}$ & 2,81 & $\mathrm{c}$ \\
\hline
\end{tabular}

Keterangan: Angka-angka yang diikuti huruf yang sama pada kolom menunjukkan tidak berbeda nyata $(5 \%)$.

Berdasarkan Tabel 1 dapat dilihat bahwa rerata kadar air sosis paling rendah adalah pada perlakuan B4 yakni $62,67 \%$ dan paling tinggi adalah pada perlakuan B0 yakni $66,04 \%$. Penambahan tepung bit menyebabkan sebagian besar air pada sosis akan terserap ke dalam pati sehingga kadar air sosis menurun. Menurut Winarno (1992), penambahan air dingin ke dalam tepung akan menyebabkan pati menyerap air dan membengkak. Selain itu Kandungan amilosa dan serat kasar pada tepung bit akan membantu penyerapan air pada granula sehingga berpengaruh meningkatkan daya serap air dalam emulsi sosis (Suarni dkk., 2013). Darojat (2010) menjelaskan, bahwa serat memiliki luas permukaan yang sangat besar dan struktur yang berbentuk kapiler sehingga memiliki kemampuan untuk menyerap air yang tinggi.

Singal dkk. (2013) melaporkan bahwa peningkatan filler berupa konsentrasi rasio $5 \mathrm{~g}$ tepung wortel dan $10 \mathrm{~g}$ tepung sagu dalam pembuatan sosis berbasis ikan gabus berpengaruh terhadap penurunan kadar air dari 66,52\% menjadi 64,48\%. Fenomena serupa juga disampaikan oleh Purohit et al., (2016) bahwa penambahan tepung kacang polong dengan konsentrasi 1,5\%-2,5\% berpengaruh terhadap penurunan kadar air sosis daging puyuh dari $75,40 \%$ menjadi 72,97\%. Menurut SNI No 01-3820-1995 kadar air sosis maksimal adalah sebesar $67,0 \%$. Berdasarkan parameter tersebut maka sosis daging puyuh dengan penambahan berbagai level tepung bit ini telah sesuai.

\section{Kadar Protein}

Berdasarkan hasil analisis sidik ragam menunjukkan perlakuan konsentrasi tepung bit berpengaruh nyata $(\mathrm{p}<0,05)$ terhadap kadar protein sosis. Rerata kadar protein sosis pada beberapa level tepung bit disajikan pada Tabel 1. 
Berdasarkan Tabel 1 dapat dilihat bahwa rerata kadar protein sosis paling rendah adalah pada perlakuan B0 yakni sebesar 12,24\% dan paling tinggi adalah pada perlakuan B4 yakni sebesar 14,66\%. Peningkatan kadar protein pada sosis tersebut dipengaruhi oleh kandungan protein yang tinggi dalam tepung bit yakni sebesar 12,80\% (Zahrat El-Ola et al., 2016). Menurut Arjuan (2008) peningkatan kadar protein akibat penambahan konsentrasi tepung bit juga dipengaruhi oleh semakin menurunnya kadar air pada produk. Hal ini dikarenakan semakin rendahnya kadar air, maka dalam pengujian protein yang menggunakan berat basah didapatkan kadar protein lebih tinggi. Semakin tinggi kadar air dalam suatu bahan, maka persentase protein dan komponen lainnya akan lebih rendah jika dibandingkan dengan suatu produk yang identik namun memiliki kadar air yang lebih rendah.

Fenomena serupa dilaporkan oleh Purohit et al., (2016) bahwa terdapat korelasi antara kadar air yang semakin menurun terhadap peningkatan kadar protein pada sosis burung puyuh dengan penambahan tepung kacang polong. Peningkatan tepung kacang polong dari konsentrasi 1,5\%-2,5\% berpengaruh terhadap peningkatan kadar protein sosis daging puyuh dari $19,13 \%$ menjadi 20,25\%. Menurut SNI No 01-3820-1995 kadar protein sosis yang sesuai standar mutu adalah sosis dengan kadar protein minimal sebesar 13\%. Berdasarkan parameter tersebut diketahui bahwa peningkatan level tepung bit memiliki peran penting agar kadar protein sosis daging puyuh dapat mencapai standar.

\section{Kadar Abu}

Berdasarkan hasil analisis sidik ragam menunjukkan perlakuan konsentrasi tepung bit berpengaruh nyata $(p<0,05)$ terhadap kadar abu sosis. Rerata kadar abu sosis pada beberapa level tepung bit disajikan pada Tabel 1.

Berdasarkan Tabel 1 dapat dilihat bahwa dapat dilihat bahwa rerata kadar abu sosis paling rendah adalah pada perlakuan B0 yakni 2,08\% dan paling tinggi adalah pada perlakuan B5 yakni 2,81\%. Semakin meningkat konsentrasi tepung bit yang digunakan berpengaruh terhadap kadar abu sosis yang semakin meningkat. Hal tersebut dipengaruhi oleh kadar abu dalam tepung bit yang cukup tinggi yakni sebesar 8,20\% (Zahrat El-Ola et al., 2016). Wruss et al., (2015) menyatakan bahwa kandungan mineral dominan pada bit adalah zat besi (Fe) yakni sebesar 1551-2995 $\mathrm{\mu g} / \mathrm{L}$. Menurut Zahrat El-Ola et al., (2016) peningkatan konsentrasi tepung bit sebesar $3 \mathrm{~g}-7 \mathrm{~g}$ dapat meningkatkan kandungan zat besi dari 1,3-1,7 mg/100 g pada produk pasta berbasis tepung gandum. Purohit et al., (2016) melaporkan bahwa Peningkatan tepung kacang polong dari konsentrasi 1,5\%-2,5\% berpengaruh terhadap peningkatan kadar abu sosis daging puyuh dari 2,07\% menjadi 2,31\%. Menurut SNI No 01-38201995 kadar abu sosis yang sesuai standar mutu adalah sosis dengan kadar abu 
maksimal sebesar 3\%. Berdasarkan parameter tersebut maka sosis daging puyuh dengan penambahan berbagai konsentrasi tepung bit ini telah sesuai.

\section{Kadar Lemak}

Berdasarkan hasil analisis sidik ragam menunjukkan perlakuan konsentrasi tepung bit tidak berpengaruh nyata $(p>0,05)$ terhadap kadar lemak sosis. Rerata kadar lemak sosis pada beberapa level tepung bit disajikan pada Gambar 1.

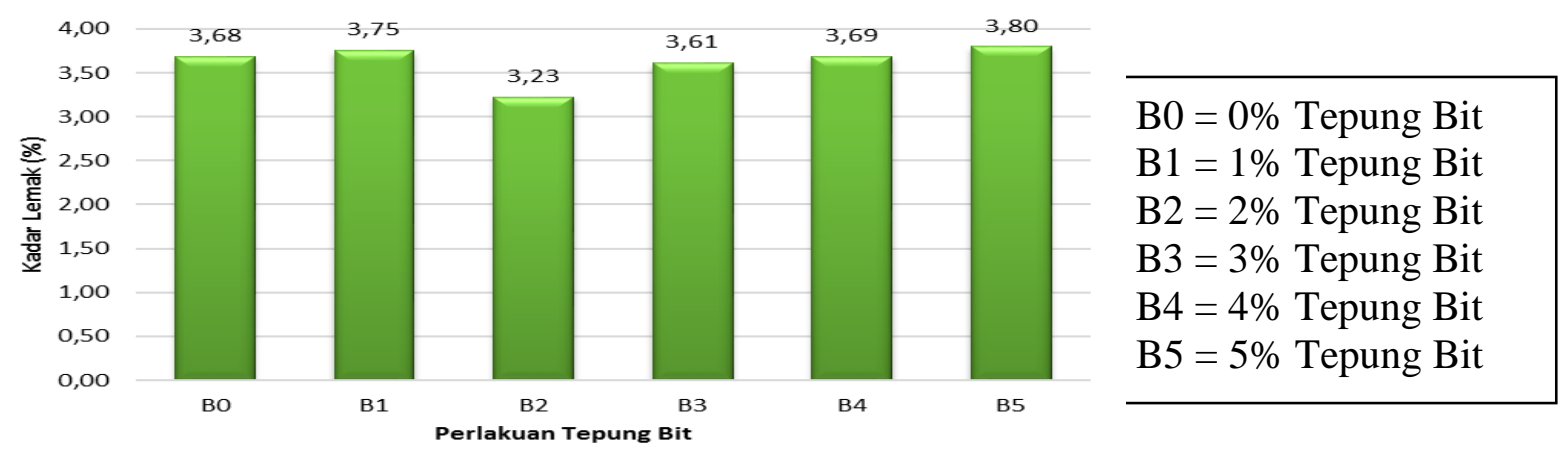

Gambar 1. Rerata Kadar Lemak Sosis Pada Berbagai Level Tepung Bit

Berdasarkan Gambar 1 dapat dilihat bahwa rerata kadar lemak sosis dengan penambahan berbagai konsentrasi tepung bit berkisar antara 3,23\%$3,80 \%$. Semakin meningkat konsentrasi tepung bit yang digunakan tidak berpengaruh terhadap kadar lemak sosis. Rendahnya kadar lemak yang diperoleh dari sosis daging puyuh dikarenakan kadar lemak daging puyuh yang rendah yakni sebesar 0,61\% (Tabel 10). Kandungan lemak dalam tepung bit juga dilaporkan rendah yakni sebesar 0,43\% (Zahrat El-Ola et al., 2016). Fenomena serupa dilaporkan oleh Singal dkk. (2013) bahwa penambahan filler berupa tepung wortel dan tepung sagu tidak berpengaruh nyata terhadap kadar lemak sosis. Kadar lemak sosis pada penelitian ini lebih tinggi dibandingkan hasil penelitian Purohit et al., (2016) sebesar 2,54-2,64\% pada pembuatan sosis daging puyuh dengan penambahan berbagai konsentrasi tepung kacang polong. Menurut SNI No 01-3820-1995 kadar lemak sosis yang sesuai standar mutu adalah sosis dengan kadar lemak maksimal sebesar 25\%. Berdasarkan parameter tersebut diketahui bahwa sosis daging puyuh dengan penambahan tepung bit telah sesuai.

\section{Aktivitas Antioksidan}

Berdasarkan hasil analisis sidik ragam menunjukkan perlakuan konsentrasi tepung bit berpengaruh nyata $(\mathrm{p}<0,05)$ terhadap aktivitas antioksidan sosis. Rerata aktivitas antioksidan sosis pada beberapa level tepung bit disajikan pada Tabel 2 . 
Tabel 2. Rerata Aktivitas Antioksidan (\%) dan Skor Tekstur (N/mm²) Sosis Pada Berbagai Level Tepung Bit

\begin{tabular}{lcccc}
\hline & \multicolumn{3}{c}{$\begin{array}{c}\text { Aktivitas Antioksidan } \\
(\%)\end{array}$} & Tekstur $\left(\mathrm{N} / \mathrm{mm}^{2}\right)$ \\
Perlakuan & 1,38 & $\mathrm{a}$ & 3,72 & $\mathrm{a}$ \\
\hline B0 (0 g tepung bit) & 11,03 & $\mathrm{~b}$ & 4,44 & $\mathrm{~b}$ \\
B1 (1 g tepung bit) & 21,01 & $\mathrm{c}$ & 4,33 & $\mathrm{ab}$ \\
B2 (2 g tepung bit) & 30,06 & $\mathrm{~d}$ & 4,54 & $\mathrm{bc}$ \\
B3 (3 g tepung bit) & 38,70 & $\mathrm{e}$ & 5,42 & $\mathrm{~d}$ \\
B4 (4 g tepung bit) & 47,95 & $\mathrm{f}$ & 5,19 & $\mathrm{~cd}$ \\
B5 (5 g tepung bit) &
\end{tabular}

Keterangan: Angka-angka yang diikuti huruf yang sama pada kolom menunjukkan tidak berbeda nyata $(5 \%)$.

Berdasarkan Tabel 2 dapat dilihat bahwa rerata aktivitas antioksidan sosis yang paling rendah adalah pada perlakuan B0 yakni 1,38\% dan paling tinggi adalah pada perlakuan B5 yakni 47,95\%. Aktivitas antioksidan pada sosis dipengaruhi oleh aktivitas antioksidan yang tinggi dalam tepung bit yakni sebesar $82,13 \%$. Sesuai dengan hasil penelitian yang dilaporkan oleh Wibawanto dkk. (2014) bahwa aktivitas antioksidan pada tepung bit yakni sebesar 81,63\%84,82\%. Saati et al., (2014) menjelaskan fenomena serupa pada bunga mawar bahwa proses penepungan menyebabkan peningkatan kadar antioksidan ditunjukkan dengan meningkatnya nilai absorbansi pada bentuk tepung dibandingkan bentuk segar. Hal tersebut salah satunya dipengaruhi oleh kadar air yang menurun sehingga kadar antosianin meningkat. Pada buah bit menurut Czapzki et al., (2009) aktivitas antioksidan dipengaruhi oleh kandungan betalain. Gugus amina pada asam betalaic baik pada betasianin maupun betaxanthin disebut dapat menyumbangkan atom hydrogen pada radikal bebas.

Sawicki et al., (2016) menyatakan bahwa penyumbang terbesar kadar antioksidan pada bit adalah bagian kulitnya dikarenakan kandungan betalain yang tinggi pada bagian kulit dibandingkan pada bagian daging buah yakni sebesar $12,79 \%$ sedangkan bagian daging sebesar 4,44\%-7,27\%. Tepung bit yang diperoleh pada penelitian ini juga menggunakan bagian kulit selain juga dagingnya. Aktivitas antioksidan pada penelitian ini lebih tinggi dibandingkan penelitian-penelitian sebelumnya. Prabowo dkk. (2013) melaporkan bahwa penggunaan konsentrasi pasta bit sebesar 5\%-15\% dapat meningkatkan aktivitas antioksidan pada sosis berbasis jamur tiram putih sebesar 7,08\%16,37\%. Zahrat El-Ola et al., (2016) melaporkan bahwa peningkatan tepung bit sebesar $3-7 \%$ dapat meningkatkan aktivitas antioksidan hingga sebesar 6-10\% dibandingkan tanpa penambahan tepung bit yakni sebesar $4 \%$ pada produk pasta berbasis tepung gandum. 


\section{Tekstur}

Berdasarkan hasil analisis sidik ragam menunjukkan perlakuan konsentrasi tepung bit berpengaruh nyata $(\mathrm{p}<0,05)$ terhadap skor tekstur sosis. Rerata skor tekstur sosis pada beberapa level tepung bit disajikan pada Tabel 2 .

Berdasarkan Tabel 2 dapat dilihat bahwa rerata tekstur sosis yang paling lunak adalah pada perlakuan B0 yakni $3,72 \mathrm{~N} / \mathrm{mm}^{2}$ dan paling keras adalah pada perlakuan B4 yakni 5,42 N/mm². Hal tersebut dipengaruhi oleh komponen dalam tepung bit yang mayoritas tersusun atas kandungan karbohidrat yang tinggi. Kadar karbohidrat pada tepung bit adalah sebesar 58,31\% (Zahrat El-Ola et al., 2016). Peningkatan kadar karbohidrat pada sosis dapat meningkatkan total padatan pada sosis yang berpengaruh terhadap kadar air sosis menjadi lebih rendah. Sesuai dengan pendapat Purohit et al., (2016) bahwa peningkatan bahan filler pada sosis dapat meningkatkan tekstur sosis menjadi lebih keras.

Pembentukan tekstur yang kenyal pada sosis juga disebabkan oleh peranan amilosa dan amilopektin pada filler. Komposisi kandungan amilosa dan amilopektin ini akan bervariasi dalam produk pangan yang mana penambahan tepung bit akan menghasilkan tekstur yang padat dan memperbaiki daya iris permukaan sosis. Penambahan tepung bit menghasilkan tingkat kekerasan yang lebih rendah pada produk sosis dibandingkan dalam bentuk pasta bit. Prabowo dkk. (2013) melaporkan tingkat kekerasan pada sosis jamur tiram putih dengan penambahan konsentrasi pasta bit sebesar 5\%-15\% adalah sebesar 6,66-7,41 $\mathrm{N} / \mathrm{mm}^{2}$. Hal ini diduga dipengaruhi oleh kadar air pada bit bentuk pasta yang lebih tinggi dibandingkan pada tepung bit sehingga menambah kadar air pada sosis yang berpengaruh pada tekstur sosis menjadi lebih lunak.

\section{Tingkat Kecerahan (L)}

Berdasarkan hasil analisis sidik ragam menunjukkan perlakuan konsentrasi tepung bit berpengaruh nyata $(p<0,05)$ terhadap tingkat kecerahan sosis. Rerata tingkat kecerahan sosis pada beberapa level tepung bit disajikan pada Tabel 3.

Berdasarkan Tabel 3 dapat dilihat bahwa rerata kecerahan sosis paling rendah adalah pada perlakuan B5 yakni 44,33 dan kecerahan paling tinggi adalah pada perlakuan B0 yakni 59,77. Semakin meningkat konsentrasi tepung bit yang digunakan berpengaruh terhadap kecerahan sosis yang semakin menurun. Hal tersebut dipengaruhi oleh komponen pigmen pada tepung bit yang merupakan betalain terdiri atas kandungan betasianin dan betaxanthin yang tinggi sehingga dapat menurunkan kecerahan pada produk. Sesuai dengan pendapat Prabowo dkk. (2013) bahwa peningkatan konsentrasi bit pada sosis dapat menurunkan kecerahan pada sosis. Peningkatan konsentrasi pasta bit dari 5\%-15\% dapat menurunkan kecerahan sosis dari 63,52-48,56. 
Tabel 3. Rerata Tingkat Kecerahan (L), Kemerahan $\left(\mathrm{a}^{+}\right)$, dan Kekuningan $\left(\mathrm{b}^{+}\right)$ Sosis Pada Berbagai Level Tepung Bit

\begin{tabular}{|c|c|c|c|c|c|c|}
\hline \multirow{2}{*}{$\frac{\text { Perlakuan }}{\text { B0 (0 g tepung bit })}$} & \multicolumn{2}{|c|}{ Kecerahan (L) } & \multicolumn{2}{|c|}{$\begin{array}{c}\text { Kemerahan }\left(\mathrm{a}^{+}\right. \\
)\end{array}$} & \multicolumn{2}{|c|}{ Kekuningan $\left(\mathrm{b}^{+}\right)$} \\
\hline & 59,77 & $\mathrm{e}$ & 10,50 & $\mathrm{a}$ & 12,57 & $\mathrm{a}$ \\
\hline B1 ( $1 \mathrm{~g}$ tepung bit) & 56,07 & d & 14,07 & b & 20,50 & $\mathrm{c}$ \\
\hline B2 (2 g tepung bit) & 51,17 & $\mathrm{c}$ & 18,23 & $\mathrm{c}$ & 19,90 & $\mathrm{c}$ \\
\hline B3 (3 g tepung bit) & 48,23 & $\mathrm{~b}$ & 21,07 & d & 16,70 & $\mathrm{~b}$ \\
\hline B4 (4 g tepung bit) & 45,93 & $\mathrm{a}$ & 22,17 & $d$ & 14,97 & $a b$ \\
\hline B5 (5 g tepung bit) & 44,33 & $\mathrm{a}$ & 25,47 & $\mathrm{e}$ & 13,20 & $\mathrm{a}$ \\
\hline
\end{tabular}

Kecerahan pada perlakuan kontrol yang tinggi adalah dikarenakan pati tapioka yang digunakan sebagai bahan filler memiliki warna yang putih. Pati tapioka mampu menghasilkan gel yang bening sehingga tidak mempengaruhi warna sosis yang dihasilkan. Gel bening tersebut dihasilkan dari proses gelatinasi yang terjadi pada pati ketika adonan sosis direbus (Purwosari, 2016).

\section{Tingkat Kemerahan $\left(\mathrm{a}^{+}\right)$}

Berdasarkan hasil analisis sidik ragam menunjukkan perlakuan konsentrasi tepung bit berpengaruh nyata $(p<0,05)$ terhadap tingkat kemerahan sosis. Rerata tingkat kemerahan sosis pada beberapa level tepung bit disajikan pada Tabel 3 .

Berdasarkan Tabel 3 dapat dilihat bahwa rerata kemerahan sosis paling rendah adalah pada perlakuan B0 yakni 10,50 dan paling tinggi adalah pada perlakuan B5 yakni 25,47. Semakin meningkat konsentrasi tepung bit yang digunakan berpengaruh terhadap kemerahan sosis yang semakin meningkat. Hal tersebut dipengaruhi oleh komponen pigmen pada tepung bit yang merupakan betalain terdiri atas kandungan betasianin dan betaxanthin yang tinggi sehingga dapat meningkatkan kemerahan pada sosis. Menurut Sawicki et al., (2016) kandungan betalain pada buah bit adalah sebesar $17,24 \%$ dengan betasianin sebagai komponen dominan yakni sebesar 12,79\% dan betaxanthin dengan jumlah yang lebih sedikit yakni sebesar $4.46 \%$. Rata-rata bit mengandung betalain sebesar $1.000 \mathrm{mg} / 100 \mathrm{~g}$ berat kering atau $120 \mathrm{mg} / 100 \mathrm{~g}$ berat basah (Andarwulan \& Faradilla, 2012).

Hasil penelitian ini sesuai dengan pendapat Prabowo dkk. (2013) bahwa peningkatan konsentrasi bit pada sosis dapat meningkatkan kemerahan pada sosis. Peningkatan konsentrasi pasta bit dari 5\%-15\% dapat meningkatkan kemerahan sosis dari 12,09-26,44. Fenomena serupa dilaporkan oleh Zahrat El- 
Ola et al., (2016) bahwa peningkaan konsentrasi tepung bit sebesar 3\%-7\% dapat meningkatkan kemerahan sebesar $13,70-44,01$ pada pasta berbasis tepung gandum.

\section{Tingkat Kekuningan $\left(\mathrm{b}^{+}\right)$}

Berdasarkan Tabel 3 dapat dilihat bahwa rerata kekuningan sosis paling rendah adalah pada perlakuan B0 yakni 12,57 dan paling tinggi adalah pada perlakuan B1 yakni 20,50. Semakin meningkat konsentrasi tepung bit yang digunakan berpengaruh terhadap kekuningan sosis yang semakin menurun. Hal tersebut dipengaruhi oleh meningkatnya kemerahan pada sosis akibat penambahan tepung bit sehingga warna kekuningan menjadi semakin menurun. Winanti dkk. (2013) melaporkan nilai kekuningan sosis tanpa penambahan bit adalah 15,93, dan sosis dengan penambahan bit 5\%, 10\% dan $15 \%$ berturut-turut yakni 17,11, 16,48, dan 14,52 sedangkan warna kemerahan semakin meningkat yakni secara berturut-turut sebesar 20,32; 26,86; dan 30,19. Fenomena serupa dilaporkan oleh Atma (2015) bahwa dengan peningkatan warna merah pada sosis daging sapi akibat ditambahkan pewarna angkak berpengaruh terhadap warna kekuningan yang semakin menurun.

\section{Aroma}

Pada Gambar 2 dapat dilihat bahwa rerata aroma sosis dengan penambahan berbagai konsentrasi tepung bit berkisar antara 3,3 - 3,6 yang berarti cukup suka. Skor aroma sosis diberi rentang antara 1-5 dengan keterangan (1) sangat tidak suka, (2) tidak suka, (3) cukup suka, (4) suka, dan (5) sangat suka. Aroma yang tidak berbeda pada sosis akibat penambahan tepung bit adalah dikarenakan tepung bit mempunyai flavor yang netral sehingga menyebabkan tidak terdapat pengaruh pada aroma sosis daging puyuh yang dihasilkan. Selain itu berdasarkan hasil penelitian diperoleh bahwa aroma sosis dengan penambahan bit masih cenderung sama dengan perlakuan kontrol. Sesuai dengan hasil penelitian Prabowo dkk. (2013) bahwa penambahan bit tidak berpengaruh terhadap aroma sosis jamur tiram putih. Fenomena serupa juga dilaporkan oleh Winanti dkk. (2013) yang menyatakan bahwa penambahan bit tidak berpengaruh terhadap aroma sosis daging sapi. 


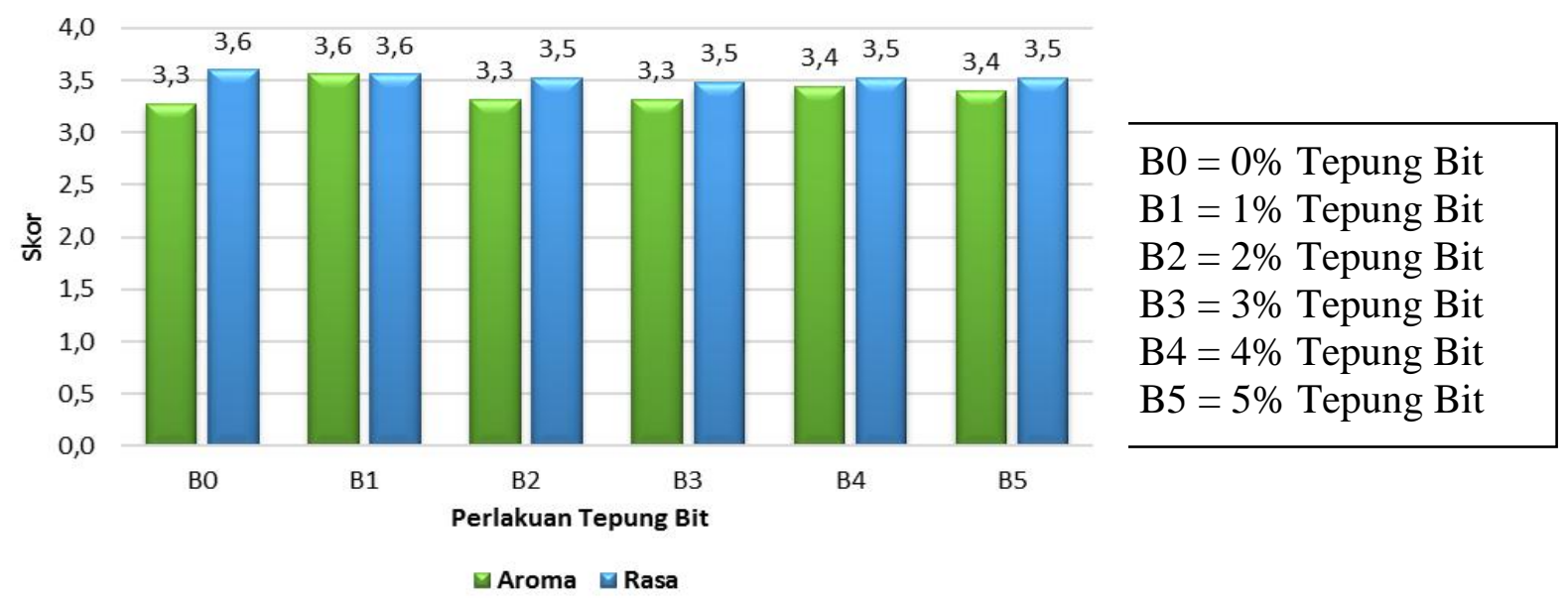

Gambar 2. Rerata Skor Aroma dan Rasa Sosis Pada Berbagai Level Tepung Bit

\section{Rasa}

Pada Gambar 2 dapat dilihat bahwa rerata skor rasa sosis dengan penambahan berbagai konsentrasi tepung bit berkisar antara 3,5 - 3,6 yang berarti cukup enak. Skor rasa sosis diberi rentang antara 1-5 dengan keterangan (1) sangat tidak enak, (2) tidak enak, (3) cukup enak, (4) enak, dan (5) sangat enak. Rasa sosis dengan penambahan bit masih cenderung sama dengan perlakuan kontrol. Sesuai dengan hasil penelitian Prabowo dkk. (2013) bahwa penambahan bit tidak berpengaruh terhadap rasa sosis jamur tiram putih. Fenomena serupa juga dilaporkan oleh Winanti dkk. (2013) yang menyatakan bahwa penambahan bit tidak berpengaruh terhadap rasa sosis daging sapi. Menurut Atma (2015), rasa sosis dapat dipengaruhi oleh beberapa faktor, diantaranya jumlah garam yang ditambahkan, bumbu-bumbu, gula dan lemak. Penambahan garam, lemak minyak, tepung, susu skim dan bumbu-bumbu selama pengolahan sama banyak pada setiap perlakuan, sehingga rasa sosis daging puyuh yang dihasilkan juga sama.

\section{Kenampakan}

Berdasarkan hasil analisis sidik ragam menunjukkan perlakuan konsentrasi tepung bit berpengaruh nyata $(p<0,05)$ terhadap skor kenampakan sosis. Rerata skor kenampakan sosis pada beberapa level tepung bit disajikan pada Tabel 4 . 
Tabel 4. Rerata Skor Kenampakan Sosis Pada Berbagai Level Tepung Bit

\begin{tabular}{lcc}
\hline Perlakuan & \multicolumn{2}{c}{ Skor Kenampakan } \\
\hline B0 (0 g tepung bit) & 2,44 & $\mathrm{a}$ \\
B1 (1 g tepung bit) & 3,24 & $\mathrm{~b}$ \\
B2 (2 g tepung bit) & 3,16 & $\mathrm{~b}$ \\
B3 (3 g tepung bit) & 3,52 & $\mathrm{bc}$ \\
B4 (4 g tepung bit) & 3,84 & $\mathrm{~cd}$ \\
B5 (5 g tepung bit) & 4,04 & $\mathrm{~d}$ \\
\hline
\end{tabular}

Keterangan: Angka-angka yang diikuti huruf yang sama pada kolom menunjukkan tidak berbeda nyata (5\%).

Pada Tabel 4 dapat dilihat bahwa rerata kenampakan sosis dengan kenampakan paling rendah adalah pada perlakuan B0 yakni 2,44 dan paling tinggi adalah pada perlakuan B5 yakni 4,04. Semakin meningkat konsentrasi tepung bit yang digunakan berpengaruh terhadap kenampakan sosis yang semakin meningkat yang mengindikasikan kenampakan sosis semakin disukai. Hal tersebut dipengaruhi oleh meningkatnya kemerahan pada sosis akibat penambahan tepung bit sehingga nilai kenampakan menjadi semakin tinggi. Menurut Prabowo dkk. (2013) semakin meningkat konsentrasi bit yang digunakan pada sosis berpengaruh terhadap kesukaan yang semakin meningkat dibandingkan perlakuan kontrol. Sedangkan Winanti dkk. (2013) melaporkan bahwa penambahan bit konsentrasi 5\% lebih disukai berdasarkan aspek warnanya dibandingkan konsentrasi $10 \%$ dan $15 \%$ hal tersebut dikarenakan semakin tinggi konsentrasi yang digunakan akan mempengaruhi warna sosis menjadi lebih gelap sehingga nilai kenampakan menjadi menurun.

\section{KESIMPULAN}

Berdasarkan penelitian ini disimpulkan bahwa perbedaan formula sosis dan konsentrasi tepung bit berpengaruh nyata terhadap kadar air, kadar protein, kadar abu, aktivitas antioksidan, tekstur, kecerahan, kemerahan, kekuningan, dan kenampakan, tetapi tidak berpengaruh nyata terhadap kadar lemak, rasa, dan aroma sosis daging puyuh yang dihasilkan. Perlakuan terbaik adalah sosis daging puyuh dengan penambahan konsentrasi tepung bit sebesar 5\% (B5) yang mempunyai karakteristik kadar air 63,52\%, kadar protein $13,44 \%$, kadar lemak 3,80\%, kadar abu 2,81\%, aktivitas antioksidan 47,95\%, tekstur 5,19 $\mathrm{N} / \mathrm{mm}^{2}$, tingkat kecerahan 44,33, tingkat kemerahan 25,47, tingkat kekuningan 13,20, aroma 3,4 (cukup suka), rasa 3,5 (cukup enak), dan kenampakan 4,04 (menarik). Semua perlakuan telah sesuai dengan standar berdasarkan SNI No. 01-3820-1995. 


\section{REFERENSI}

Andarwulan N., dan Faradilla Fitri R.H. 2012. Pewarna Alami untuk Pangan. Bogor: SEAFAST CENTER IPB.

Arjuan, Herrisdiano, 2008. Aplikasi Pewarna Bubuk Ekstrak Umbi Bit (Beta vulgaris) Sebagai Pengganti Pewarna Tekstil Pada Produk Terasi Kabupaten Berau Kalimantan Timur. Skripsi. Program Studi Hasil Perikanan. Fakultas Perikanan dan Ilmu Kelautan. IPB.

Atma Y. 2015. Studi Penggunaan Angkak Sebagai Pewarna Alami dalam Pengolahan Sosis Daging Sapu. Jurnal Teknologi. 7(2): 76-85.

Badan Standardisasi Nasional (BSN). 1995. SNI No 01-3820-1995: Sosis Daging. Jakarta: Badan Standarisasi Nasional.

Czapski J., Mikolajcyk K., dan Kaczmarek M. 2009. Relationship Between Antioxidant Capacity of Red Beet Juice and Contents of its Betalain Pigments. Polish Journal of Food and Nutrition Sciences. 59(2):119-122.

Darojat, D. 2010. Manfaat Penambahan Serat Pangan pada Produk Daging Olahan. Majalah Food Review. 5(7): 52-53.

Kartikayudha, W., Isroli., Suprapti, N.H. 2014. Kadar Protein dan Bobot Daging Puyuh Setelah Pemberian Bahan Tambahan Pakan Tepung Ikan Swangi dan Periodisasi Waktu Pemberian Tepung Kunyit Yang Berbeda Pada Ransum. Buletin Antomi dan Fisiologi. 21(1): 17-29.

Pasaribu, D.T.Y. 2009. Pengaruh Taraf Penambahan Tepung Terigu Sebagai Bahan Pengikat Terhadap Kualitas Sosis Daging Ayam. Skripsi. Medan: USU.

Prabowo D.H., Andriani M.A.M., dan Nurhartadi E. 2013. Pengaruh Penambahan Bit (Beta Vulgaris L.) Sebagai Pewarna Alami dan Bahan Pengisi Terhadap Karakeristik Fisikokimia dan Sensori Sosis Nabati. Jurnal Teknosains Pangan 2(4): 12-17.

Purohit, A., Reed, C., Mohan, A., Development and Evaluation of Quail Breakfast Sausage. LWT - Food Science and Technology, doi: 10.1016/j.lwt.2016.01.058.

Purwosari A.G. Pengaruh Penggunaan Jenis dan Jumlah Bahan Pengisi Terhadap Hasil Jadi Sosis Ikan Gabus (Channa striata). E-journal Boga. 5(1): 211-218.

Pusat Penganekaragaman Konsumsi dan Keamanan Pangan dalam Data Statistik Ketahanan Pangan. 2014. Perkembangan Konsumsi Energi dan Kualitas Konsumsi Pangan Penduduk Indonesia 2010-2014. Jakarta: Badan Ketahanan Pangan Kementrian Pertanian.

Saati E.A., Aisyah R., Wachid M., dan Winarsih S. 2014. Non-Alcoholic Extraction of Rose Pigment as a Halal and Safe Natural Colorant and Bioactive Compound. JISTECS 2(2): 65-70.

Sawicki T., Baczek N., dan Wiczkowski W. 2016. Betalain Profile, content and antioxidant capacity of red beetroot dependent on the genotype and root part. Journal of Functional Foods 27: 249-261.

Singal C.Y., Nurali E.J.N., Koapaha T., dan Djarkasi G.S.S. 2013. Pengaruh Penambahan Tepung Wortel (Daucus carota L) Pada Pembuatan Sosis 
Ikan Gabus (Ophiocephalus striatus). http:/lejournal.unsrat.ac.id/. (Diakses 23 Agustus 2017).

Suarni, Firmansyah I.U., dan Aqli M. Keragaman Mutu Pati Beberapa Varietas Jagung. Penelitian Pertanian Tanaman Pangan. 32(1): 50-56.

Wibawanto, N.R., Ananingsih, V.K., dan Pratiwi, R. 2014. Produksi Serbuk Pewarna Alami Bit Merah (Beta Vulgaris L.) Dengan Metode Oven Drying. Prosiding SNST. Semarang: Universitas Wahid Hasyim.

Winanti E.R., Andriani, M.A.M., dan Nurhartadi, E. 2013. Pengaruh Penambahan Bit (Beta vulgaris) Sebagai Pewarna Alami Terhadap Karakteristik Fisikokimia Dan Sensori Sosis Daging Sapi. Jurnal Teknosains Pangan 2(4): 18-24.

Winarno, F. G. 1992. Kimia Pangan dan Gizi. PT Gramedia Pustaka Utama. Jakarta.

Wruss J., Waldenberger G., Huemer S., Uygun P., Lanzerstorfer P., Muller U., Hoglinger O., dan Weghuber J. 2015. Compositional characteristics of commercial beetroot products and beetroot juice prepared from seven beetroot varieties grown in Upper Austria. Journal of Food Composition and Analysis. 42: 46-55.

Zahrat El-Ola M. Mohamed, Ghada H. H. Ismaiel, Ayat E. Rizk. 2016. Quality Characterizations of Pasta Fortified with Red Beet Root and Red Radish. International Journal of Food Science and Biotechnology. 1(1): 1-7. 